\title{
Physiological and biochemical changes associated with massive mortality events occurring in larvae of American oyster (Crassostrea virginica)
}

\author{
Bertrand Génard ${ }^{1}$, Fabrice Pernet ${ }^{2,3, a}$, Karine Lemarchand ${ }^{1}$, Pierre Boudry ${ }^{4}$, Dario Moraga ${ }^{5}$ \\ and Réjean Tremblay ${ }^{1}$ \\ ${ }^{1}$ Institut des sciences de la mer, Université du Québec à Rimouski, 310 allée des Ursulines, Rimouski, Québec G5L 3A1, Canada \\ 2 Institut de recherche sur les zones côtières, 232b rue de l'Eglise, Shippagan, Nouveau-Brunswick E8S 2L7, Canada \\ 3 Ifremer, Laboratoire Environnement Ressources du Languedoc Roussillon, bd Jean Monnet, 34203 Sète, France \\ ${ }^{4}$ Ifremer, UMR M100 Physiologie et Ecophysiologie des Mollusques marins, 29280 Plouzané, France \\ 5 Institut Universitaire Européen de la Mer, Laboratoire des Sciences de l'Environnement marin, Université de Bretagne occidentale, \\ 29280 Plouzané, France
}

Received 15 September 2010; Accepted 21 April 2011

\begin{abstract}
In this paper, biochemical and physiological analyses were used to characterize changes associated with mortality event occurred during veliger development of American oyster, Crassostrea virginica. Biochemical analyses included the evaluation of lipid classes, fatty acid composition and total protein content. Larval physiology was evaluated by studying feeding activity, enzymes related to energy metabolism, oxidative stress levels and enzymatic antioxidant defenses. These analyses were complemented by bacterial community analyses as well as by measuring larval oyster performance. We observed that mortality events coincided with (1) strong changes in the surrounding bacterial community; (2) a progressive decrease in feeding activity; (3) higher levels of some lipid classes (free fatty acids, diglycerides, and acetone mobile phospholipids); (4) lower levels of phospholipids and protein; (5) higher contents of non-methylene interrupted dienoic fatty acids (22:2 NMI); (6) a decrease in energy metabolism activity (citrate synthase and cytochrome oxidase activities); (7) a higher oxidative stress (lipid peroxidation level); and (8) an activation of antioxidant defences before mortality (glutathione peroxidase and superoxide dismutase). We hypothesized that mortality emergence was related to higher energy consumption coupled with the progressive decline in feeding activity, lowered energy reserves and a decrease in energy metabolism activity. Thus, the low energy availability limited the efficiency of antioxidant defenses, resulting in a higher oxidative stress.
\end{abstract}

Key words: Massive mortality / Larvae / Microbial environment / Lipid / Fatty acids / Energy metabolism / Oxidative stress / Antioxidant enzymes / Crassostrea virginica

\section{Introduction}

In bivalve aquaculture, mass mortality of larvae is a regular event. The origin of this phenomenon can be multifactorial, including abiotic and/or biotic factors (Paillard et al. 2004). In hatchery, it is often associated with the degradation of rearing environment. In bivalves larvae, the physiological, and biochemical changes associated with the emergence of mortality event are poorly documented. Therefore, firstly in this project, biochemical and physiological parameters involved in larval development success and/or stressful condition were studied in relation to mortality occurrence.

Development success in larval bivalves is related to their capacity to accumulate lipids, which are essential to

a Corresponding author: fabrice.pernet@ifremer.fr sustain larval growth and survival (Holland and Spencer 1973; Delaunay et al. 1992, Ben Kheder et al. 2010a). A previous study on sea scallop larvae showed that levels of triacylglycerol (TAG), which constitutes the main energy source during larval development, are higher in animals treated with an antibiotic than in non-treated controls, where significant mortality occurred (Pernet et al. 2006a). In regard of these studies, we hypothesized that the lipid class composition in larvae is a good indicator of energy acquisition and overall health of larvae.

Polyunsaturated fatty acids (PUFA) are essential for sustaining growth and improving survival in several bivalve species (Langdon and Waldock 1981; Delaunay et al. 1993). $\mathrm{C}_{20}$ PUFAs, such as eicosapentaenoic acid (EPA, 20:5n3 ) and arachidonic acid (ARA, 20:4n-6), are precursors of 
eicosanoids, a group of highly biologically active hormones that includes prostaglandins, leukotrienes and hydroxyeicosatetraenoic acids (Smith and Murphy 2003). Eicosanoid production is associated with stressful situations, with excess eicosanoid production having been recorded under pathological conditions (Bell and Sargent 2003). ARA levels in sea scallop show a marked increase during the metamorphic stage, which coincides with elevated mortality and the establishment of pathogenic and opportunistic microbes in larval cultures (Pernet et al. 2005). Therefore, fatty acid composition, and more particularly ARA, is an indicator of health in marine larvae.

Larval development could be evaluated by the abilities of larvae to transform energetic substrates in ATP. Given that ATP formation involves mainly the aerobic oxidation of lipids, proteins and carbohydrates in mitochondria by means of enzymatic complexes of the citric acid cycle and electron chain transport, the energetic status of oyster can be evaluated by measuring the activities of key enzymes like citrate synthase (citric acid cycle) and cytochrome $c$ oxidase (electron chain transport) (Garcia-Esquivel et al. 2002; Moran and Manahan 2004; Ivanina et al. 2011). Here we hypothesize that the activities of key enzymes associated with physiological energy reserves and feeding activity in larvae reflect the organism maintenance cost and energy acquisition.

Larval development success can also depend on accurate antioxidant defenses. Dandapat et al. (2003) found that the antioxidant defenses play an important role in providing protection to the developing larvae from oxidative assault. Moreover, studies show that Pacific oysters infected with Vibrio exhibit an enhanced production of reactive oxygen species (ROS) by immunocompetent cells referred to as hemocytes (Labreuche et al. 2006a,b). These microbicidal oxygen derivatives could be detrimental to oyster cells, inducing oxidative stress and tissue peroxidation. To avoid these processes, ROS content are controlled by antioxidant defense systems. Oysters susceptible to summer mortalities exhibit a higher level of ROS compared to that of resistant animals before mortality event, thus linking mortality with the antioxidant disorder of the sensitive oysters (Lambert et al. 2007; Samain et al. 2007). Recent study using microarray analysis demonstrated the activation of antioxidant processes after Perkinsus marinus challenge in $C$. virginica (Wang et al. 2010). Therefore, we hypothesize that the estimation of the antioxidant enzyme activities is a useful tool to monitor the oxidative stress associated with massive mortality emergence.

The objectives of the current paper were to estimate changes associated with massive mortality emergence by studies of (1) larval growth and survival; (2) bacterial environment; (3) the protein, lipid class and fatty acid content of larvae; (4) energetic metabolism and (5) antioxidant defenses and lipids peroxidation of larvae.

\section{Materials and methods}

\subsection{Rearing procedures}

This work was conducted at the Coastal Zone Research Institute (CZRI) hatchery in Shippagan (New Brunswick,
Canada) and took place from mid-January to February 2006. Adult oysters were collected at an aquaculture grow-out site in Bouctouche (New Brunswick, Canada; 46 $49^{\prime} \mathrm{N}, 64^{\circ} 67^{\prime} \mathrm{W}$ ) and placed in $240 \mathrm{~L}$ tanks in the laboratory. Temperature was gradually increased from $-1{ }^{\circ} \mathrm{C}$ to $20{ }^{\circ} \mathrm{C}$ over a period of 20 days and maintained for another four weeks with the continuous addition of food (three microalgae species: Isochrysis sp. [T-ISO], Pavlova lutheri [MONO] and Chaetoceros muelleri [CHGRA] in equal proportions). When males and females reached sexual maturity, spawning was induced by thermal shock and the fertilized eggs were transferred to a

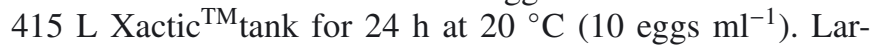
vae (10 ind. $\mathrm{ml}^{-1}$ initially) were reared in the same kind of Xactic tank at $15{ }^{\circ} \mathrm{C}$ in filtered seawater (double cartridgefiltered: $1 \mu \mathrm{m}$ and $0.5 \mu \mathrm{m}$ ) with gentle aeration. Larvae were fed a mixture of MONO, T-ISO and CHGRA at $35 \times 10^{3}$ algal cells $\mathrm{ml}^{-1}$. Algae were batch-cultured in $f / 2$ medium (with no Si for flagellates; Guillard 1975) at $20^{\circ} \mathrm{C}$ and under continuous illumination in $25 \mathrm{~L}$ carboys continuously supplied with $\mathrm{CO}_{2}$ to maintain $\mathrm{pH}$ between 7.5 and 8 .

\subsection{Experimental design}

Two days after fertilization, D-stage larvae were collected on a $44 \mu \mathrm{m}$ square mesh filter, visually counted (binocular) and divided equally into six Xactic tanks. Larvae were cultured in triplicate tanks $\left( \pm 3.5 \times 10^{6}\right.$ larvae per tank $)$ with or without an antibiotic (chloramphenicol at $4 \mathrm{mg} \mathrm{ml}^{-1}$; Fluka, Missisauga, ON). The antibiotic was used in this study to generate two different bacterial environments. Water renewal, food replacement and antibiotic treatment were conducted every 2 3 days. Samples for lipid, enzymatic and microbiological analyses were collected at 2, 6, 13, and 20 days post fertilization (dpf). Eggs were also collected for lipid analyses.

\subsection{Larval performance}

Shell length (SL), survival rate (\% of live larvae based on initial number) and feeding activity (number of cleared algal cells per larvae per day) were determined in tanks at each water change. Sieved larvae were transferred into $20 \mathrm{~L}$ buckets. Three $1 \mathrm{ml}$ subsamples of larvae were removed from each bucket and the concentration of live larvae was determined visually using a binocular microscope (Leitz Labovert, Wetzlar, Germany). SL was estimated with a Moticam 320 camera coupled to the binocular microscope; at least 50 live larvae per tank were measured to determine the mean SL using Motic Images and version 2.0 software (DC Imaging, California, USA). Microalgal cell consumption was measured with a Beckman-Coulter Z2 electronic particle counter using a $100 \mu \mathrm{m}$ probe (Beckman, USA). After food delivery and homogenization, enriched seawater was sampled in triplicate in each tank to measure the initial cell concentration. An additional sample was taken the following day $( \pm 24 \mathrm{~h}$ later $)$ and food uptake (feeding activity) was evaluated as clearance rate, i.e. $\left(N_{t=0}-N_{t=24}\right) /$ number of live larvae per $\mathrm{ml}$, where $N$ is the concentration of microalgal cell per ml introduced $(t=0)$ and after $24 \mathrm{~h}(t=24)$. 


\subsection{Lipid class and fatty acid analyses}

Microalgae and larvae were filtered onto $450{ }^{\circ} \mathrm{C}$ precombusted $\mathrm{GF} / \mathrm{C}$ filters and stored in dichloromethane under a nitrogen atmosphere at $-80{ }^{\circ} \mathrm{C}$ until extraction by the method of Folch et al. (1957) as described by Pernet et al. (2005). Lipid classes were determined using S-III chromarods and a flame ionization detection system (FID; Iatroscan MK-6S, Iatron Laboratories Inc., Tokyo, Japan) as described by Parrish (1999). This method separates aliphatic hydrocarbons, sterol and wax esters, ketones, triacylglycerols, free fatty acids, free fatty alcohols, free sterols, diacylglycerols, acetone mobile polar lipids and phospholipids.

Fatty acid profiles of microalgae and larvae were determined by gas chromatography. Neutral and polar fractions were extracted by column chromatography on deactivated silica (Pernet et al. 2006b). Fatty acid methyl esters (FAME) from polar lipids were prepared using $2 \% \mathrm{H}_{2} \mathrm{SO}_{4}$ in methanol following Lepage and Roy (1984). FAME were analyzed with a GC-FID (model 8610C, SRI, Torrance, CA, USA) equipped with a DB-WAX column (polyethylen glycol, $30 \mathrm{~m} \times 0.25 \mathrm{~mm}$ DI $\times 0.25 \mu \mathrm{m}$; Agilent). Hydrogen was used as the carrier gas and samples were injected directly onto the column. FAME were identified by comparison of retention times with known standards (37 component FAME mix, Menhaden fish oil; Supelco, Bellefonte, CA, USA).

Chromatograms were analyzed using Peak Simple version 3.21 (SRI). The peroxidation index (PI) of polar lipids was calculated as PI $=0.025(\%$ monoenoics $)+1 \times(\%$ dienoics $)+$ $2 \times(\%$ trienoics $)+4 \times(\%$ tetraenoics $)+6 \times(\%$ pentaenoics $)$ $+8 \times(\%$ hexaenoics $)$.

\subsection{Bacterial analyses}

Bacterial analyses were carried out by the Research and Productivity Council (RPC) laboratory in Fredericton (NB, Canada). Samples of oyster larvae were collected in tubes containing $3 \mathrm{ml}$ of the nucleic acid fixative RNAlater (Ambion) and stored at $4{ }^{\circ} \mathrm{C}$ according to RPC recommendations; these samples were used for the characterization of the total bacterial community associated with the larvae using the method employed by Griffiths et al. (2001). Details of the protocol used by the RPC laboratory are available in Plante et al. (2007). Briefly, the microbial community was analyzed after DNA extraction by polymerase chain reaction (PCR) followed by denaturing gradient gel electrophoresis (DGGE) using 16S rDNA gene primer sets (p515f: gccagcagccgcggtaa; E. coli position 515533; p806r: ggactaccagggtatctaat; E. coli position 806-787) for the PCR. The DGGE was performed with a gradient of 40$70 \%$ urea-formamide mixture and a non-denaturing $4 \%$ acrylamide stacking gel. The number of bands, corresponding to different operational taxonomic units (OTU), was determined visually for each sample. A similarity matrix using Jaccard's distance index $\left(S_{\text {jaccard }}\right)$ was used to compare the fingerprints. To compare the positions of each band between gels, the ratio of the distance of sample migration to the last ladder band migration was calculated ( $\mathrm{Rf}$ value).

The Jaccard index was calculated as $S_{\text {jaccard }}=N_{\mathrm{AB}} /\left(N_{\mathrm{A}}+\right.$ $\left.N_{\mathrm{B}}-N_{\mathrm{AB}}\right)$, where $N_{\mathrm{AB}}$ is the number of similar bands between samples $\mathrm{A}$ and $\mathrm{B} ; N_{\mathrm{A} \text { or B }}$ is the sum of all bands in sample $\mathrm{A}$ or B. In addition cultivable bacterial and the presumptive Vibrio load in larval tanks were estimated by mean colonies counts on Marine agar 2216 E (Difco) and TCBS agar (Thiosulfate Citrate Bile Sucrose, Difco) plate respectively. For this, water tank samples were serially diluted 10 -fold and colonies were counted after incubation for $24 \mathrm{~h}$ for TCBS agar and $72 \mathrm{~h}$ for Marine agar at $20^{\circ} \mathrm{C}$.

\subsection{Spectrophotometric analyses}

At each sampling time, 150000 to 75000 (depending to ontogenic stage) larvae were collected per tank on a $44 \mu \mathrm{m}$ square mesh filter and stored at $-80{ }^{\circ} \mathrm{C}$. Samples were weighed and homogenized $(w / v=1 / 5)$ in phosphate buffered saline (PBS: $80 \mathrm{mM}$; pH 7.6 at $25^{\circ} \mathrm{C}$ ) with $0.1 \%(v / v)$ triton $\mathrm{X}-100$ in a glass Potter homogenizer in an ice bath. A fraction $(50 \mu \mathrm{l})$ of the homogenate was removed and stored at $-80{ }^{\circ} \mathrm{C}$ for protein concentration determination using Bradford method (Protein assay Kit, Biorad). The remaining homogenate was centrifuged $(15000 \mathrm{~g})$ at $4{ }^{\circ} \mathrm{C}$ for $10 \mathrm{~min}$ and the supernatant was stored at $-80^{\circ} \mathrm{C}$ then used for enzyme activity assays as well as for the analysis of the malondialdehyde (MDA) contents. Five enzymes were selected, two to investigated the activity of energetic metabolism (citrate synthase, cytochrome $c$ oxidase) and three to monitor the antioxidant properties (glutathione peroxidise, superoxide dismutase, catalase).

The citrate synthase (CS, EC 4.1.3.7) activity was analyzed using the method of Childress and Somero (1979). The assay reaction is based on the reaction of 5,5-dithiobis(2nitobenzoic acid) (DTNB) with the reactive $-\mathrm{SH}$ group of the free co-enzyme A. The 2-nitro (2-thiobenzoic acid) (NTB) produced is yellow and absorbs maximally around $412 \mathrm{~nm}$. The cytochrome $c$ oxidase (CCO, EC 1.9.3.1) assay is based on the oxidation of ferrocytochrome $c$ and was monitored spectrophotometrically at $550 \mathrm{~nm}$ following the method of Yonetani (1967). For antioxidant enzymes, the catalase (CAT, EC 1.11.1.6) activity was determined using the Amplex®Red Catalase Assay Kit (Invitrogen, USA) according protocol of the manufacturer. This commercial kit uses the horseradish peroxidase (HRP)-catalyzed oxidation of 9-acetylresorufin to fluorescent resorufin with a maximal emission at $587 \mathrm{~nm}$. Amplex Red reacts with $\mathrm{H}_{2} \mathrm{O}_{2}$ according to a strict stoichiometric ratio of $1: 1$. The glutathione peroxidase (GPX, EC 1.11.1.9) was assayed by the method of Paglia and Valentine (1967) using t-butylhydroperoxide (tBHP) as the substrate. GPX was estimated spectrophotometrically at $340 \mathrm{~nm}$, measuring the consumption of NADPH necessary to regenerate glutathione (GSH) by glutathione reductase (GR, EC 1.6.4.2). The superoxide dismutase (SOD, EC 1.15.1.1) activity was measured spectrophotometrically according to the methods of McCord and Fridovich (1969) and Flohé and Ötting (1985). In this method, inhibition of the cytochrome $c$ reduction rate is monitored at $550 \mathrm{~nm}$ at $25{ }^{\circ} \mathrm{C}$ utilizing the hypoxantine/xantine oxidase (XOD) system as the source of superoxide $\left(\mathrm{O}_{2}{ }^{\circ}\right)$. SOD competes for $\mathrm{O}_{2}^{\circ}$ and decreases the reduction rate of cytochrome $c$. Except for SOD where one unit of activity was defined as the amount of enzyme that inhibits the rate of cytochrome $C$ reduction by $50 \%$, enzyme activity 
was defined as pmol of substrate transformed per minute, expressed per larva or ng of protein. Oxidative stress was investigated trough the lipid peroxidation levels using the malondialdehyde (MDA) content of larvae, MDA was measured with BIOXYTECHO MDA-586 ${ }^{\mathrm{TM}}$ assay kits (Oxisresearch, Portland, Oregon, USA). This method is based on the reaction of a chromogenic reagent, N-methyl-2-phenylindole (R1, NMPI), with MDA at $45^{\circ} \mathrm{C}$. Two molecules of N-methyl-2phenylindole (NMPI) react with one molecule of malondialdehyde (MDA) to yield an intensely coloured carbocyanine dye with a maximum absorption at $586 \mathrm{~nm}$.

\subsection{Statistical analyses}

Analyses were carried out using SAS®)software (version 8.2). The significance value for all analyses was set at $p<$ 0.05 . A mixed model with repeated measures (time) was used to determine whether the effects of time, treatment (antibiotic or not) and interaction of both were significant between 6 and $20 \mathrm{dpf}$. Compound symmetry was used as a covariance structure. When differences were detected, LSMEANS a posteriori comparison tests were used. Residuals were graphically assessed for normality. Homogeneity was tested using the O'Brien test. When normality and homogeneity precepts were not realized, data were log-transformed. Data are presented as means \pm standard deviations. Simple linear regressions were used to test mutual correlations between activities of CS, CCO, CAT, GPX and SOD, and between enzyme activities and MDA. Linear regressions were performed separately on data from untreated and antibiotic treated larvae. Nine points $(n=9)$ were used for each regression, corresponding to the triplicate tanks at the three development times $(6,13$ and $20 \mathrm{dpf}$ ). Regression were carried out using Sigma plot 8.0 (SYSTAT Software Inc, USA).

\section{Results}

\subsection{Survival, growth and feeding activity}

The survival rate was not significantly different between tanks during the first 17 days of the experiment, with a progressive decline from D-stage larvae to $17 \mathrm{dpf}$ to reach values near $75 \%$ (Fig. 1). At $20 \mathrm{dpf}$, a massive mortality occurred in untreated tanks, with a survival rate of $7 \pm 3 \%$ compared to $66 \pm 5 \%$ in the antibiotic treatment. Untreated and antibiotic treated larvae showed similar shell lengths, with an average growth rate of $\sim 5.4 \mu \mathrm{m} \mathrm{day}^{-1}$ between 6 and $20 \mathrm{dpf}$. Feeding activities were similar between treatments until $15 \mathrm{dpf}$ and increased progressively with time. After $15 \mathrm{dpf}$, feeding activity patterns differed between untreated and antibiotic treated larvae (Fig. 1). The feeding activity of untreated larvae decreased progressively and became null in moribund larvae at $20 \mathrm{dpf}$. In the antibiotic treatment, larvae showed an opposite trend: their feeding activity increased significantly between 17 and 20 dpf (Fig. 1). Microscopic observations of moribund larvae at $20 \mathrm{dpf}$ showed larvae weakly swimming in circles with their velum partially retracted or reduced followed by the appearance of ciliated protists.
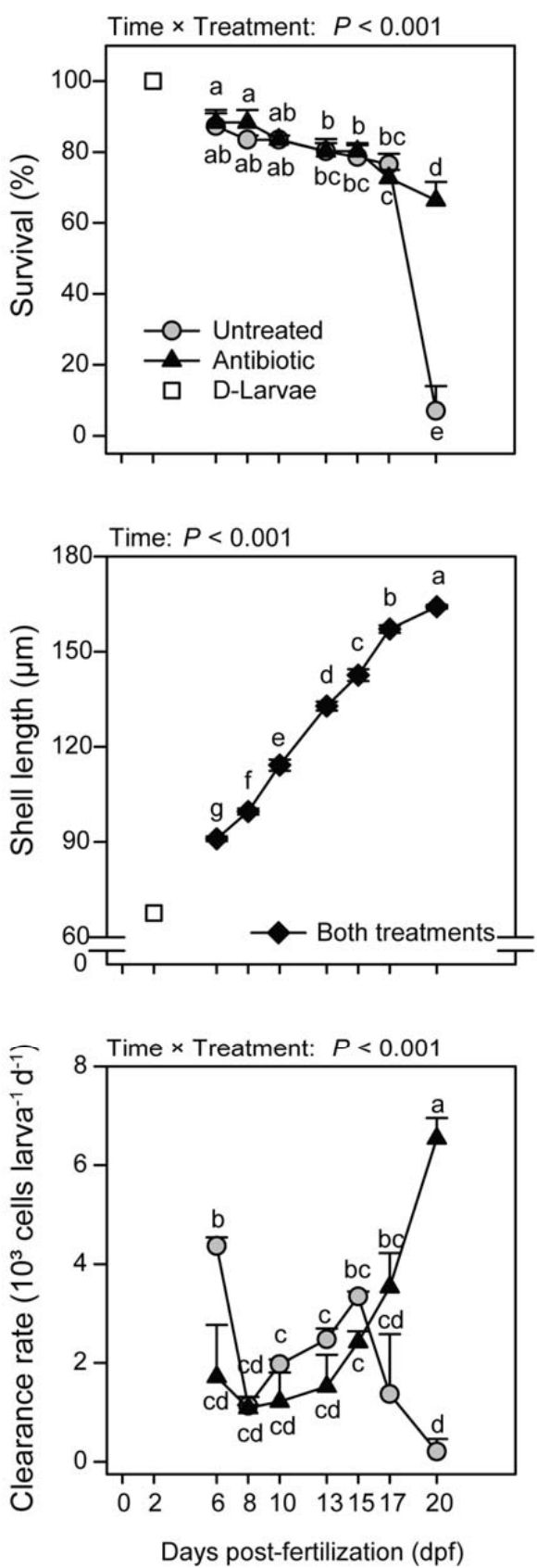

Fig. 1. Survival, shell length and clearance rate for American oyster Crassostrea virginica larvae as a function of development time and seawater treatment. Seawater was untreated or treated with an antibiotic. Data from different treatments were pooled when this effect was not significant. Data are means \pm SD of three replicate tanks. Different letters indicate significant differences.

\subsection{Bacterial analyses}

Significant interaction effect $(p<0.0001)$ between time and treatment was found for the cultivable bacterial load. It increased significantly $(p<0.05)$ between 13 and $20 \mathrm{dpf}$ in the both treatments and were significantly lower $(p<0.05)$ in tanks treated with the antibiotic (Count in CFU ml ${ }^{-1}$ : antibiotic $(13 \mathrm{dpf})=2 \pm 1 \times 10^{3}$; antibiotic 


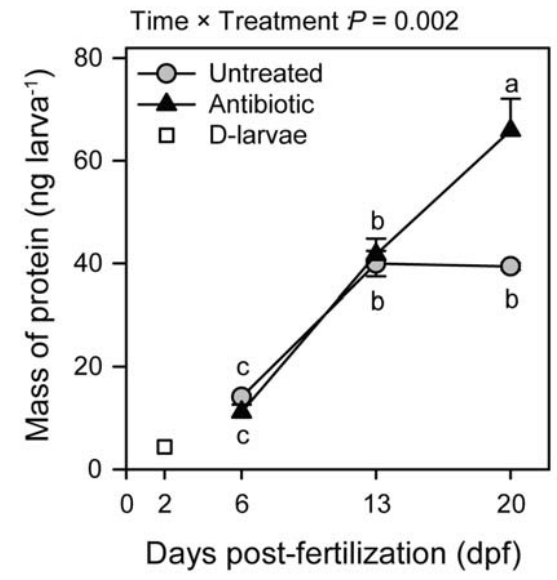

Fig. 2. Mass of protein in American oyster Crassostrea virginica as a function of development time and seawater treatment. Seawater was untreated or treated with an antibiotic. Data are means \pm SD of three replicate tanks. Different letters indicate significant differences.

$(20 \mathrm{dpf})=13 \pm 5 \times 10^{3} ;$ untreated $(13 \mathrm{dpf})=14 \pm 3 \times 10^{3} ;$ untreated $\left.(20 \mathrm{dpf})=82 \pm 8 \times 10^{3}\right)$. Except in one tank at $20 \mathrm{dpf}$, no colonies were detected in TCBS plate for antibiotic treatment, while it increased significantly $(p<0.05)$ between 13 and 20 $\mathrm{dpf}$ in untreated tanks (Count in CFU ml ${ }^{-1}: 13 \mathrm{dpf}=13 \pm 1$ $6 ; 20 \mathrm{dpf}=1127 \pm 500$ ), illustrating that an increase of cultivable bacterial and presumptive vibrio content in untreated larval tanks coincided with the massive mortality emergence.

An examination of the Jaccard index $\left(S_{\text {jaccard }}\right)$ showed that the similarity in the bacterial community between untreated and antibiotic treated larvae decreased progressively with time to reach the lowest value at $20 \mathrm{dpf}\left(S_{\text {jaccard }}: 6 \mathrm{dpf}=74 \%\right.$, $13 \mathrm{dpf}=54 \%, 20 \mathrm{dpf}=16 \%$ ).

\subsection{Protein and lipid class contents}

After fertilization, proteins were accumulated until $13 \mathrm{dpf}$ at a rate of $\sim 3.3 \mathrm{ng}$ larva ${ }^{-1}$ day $^{-1}$ to reach a mean value of $41 \mathrm{ng} \operatorname{larva}^{-1}$ (mean for antibiotic treated and untreated larvae). At $20 \mathrm{dpf}$, protein content of untreated larvae remained constant whereas it continued to increase in antibiotic treated oysters until reaching $66 \mathrm{ng} \mathrm{larva}^{-1}$ (Fig. 2).

Independently of the antibiotic treatment, larvae showed consumption of TAG from egg reserves until $6 \mathrm{dpf}$ followed by a stabilization until $13 \mathrm{dpf}$ (Fig. 3) and an increase at 20 dpf. While FFA and DG contributed $<5 \%$ of the total lipids, their levels in antibiotic treated and untreated larvae increased until the end of the experiment (Fig. 3). FFA and DG concentrations were higher in moribund larvae than in antibiotic treated larvae at $20 \mathrm{dpf}$. AMPL, a lipid class that includes photosynthetic pigments, glycolipids and monoacylglycerol, was not significantly different during the first 13 days of development but was $\sim 2$ fold higher in untreated larvae than in larvae with antibiotic treatment when mortality occurred at $20 \mathrm{dpf}$ (Fig. 3). Finally, levels of sterols (ST) and phospholipids (PL) increased throughout larval development (Fig. 3). However, at $20 \mathrm{dpf}$, PL accumulated at a lower rate in moribund larvae than in those treated with antibiotic, where no significant mortality occurred.

\subsection{Fatty acid composition}

Particular emphasis is given in this study to the major long-chain PUFAs 22:6n-3 (DHA), 20:5n-3 (EPA) and 20:4n-6 (ARA), which are commonly referred to as essential. Only ontogenetic effects were observed in the proportions of docosahexaenoic acid (DHA) and arachidonic acid (ARA) (Table 1). After fertilization, DHA was accumulated until $13 \mathrm{dpf}$ at a rate of $\sim 1.3 \pm 0.03 \% \mathrm{day}^{-1}$ to reach a mean value of $16.9 \%$ (mean for both treatments in polar lipids). Following this period of accumulation, the DHA proportion decreased slightly (Table 1). Overall, levels of DHA in polar lipids of larvae were much higher than that of the diet. In contrast, EPA that had accumulated in egg membranes declined during the first two days of development after which this level was maintained at around $8 \%$ until $20 \mathrm{dpf}$, which is well below the level measured in the diet. The polar lipids of larvae were characterized by a period of enrichment in ARA during early development: between the egg and D-larva stages, ARA made up nearly $9 \%$ of the total fatty acids compared to $3.3 \%$ in the diet. After this period of accumulation, ARA was rapidly consumed, reaching a value between 2 and $4 \%$ of total fatty acids of polar lipids, which is below the level measured in the diet (Table 1).

Interestingly, development time and seawater treatment interacted in their affects on the non-methylene interrupted dienoic fatty acids (22:2 NMI), a group of long-chain PUFA naturally biosynthesized by mollusks. Overall, the level of 22:2 NMI increased by ca. $2 \times$ during larval ontogeny from 2 to $20 \mathrm{dpf}$. However, 22:2 NMI was $12 \%$ higher in untreated oysters compared to that of animals treated with antibiotic at $20 \mathrm{dpf}$, when mortality occurred ( $p=0.019$, Table 1$)$. Finally, the peroxidation index of polar lipids was ca. 242 at $13 \mathrm{dpf}$ independently of seawater treatment and decreased by $8.6 \%$ to 223 ( $p=0.017$ ) in untreated oysters at $20 \mathrm{dpf}$, when mortality occurred, reflecting peroxidation of membrane lipids. In contrast, the peroxidation index of oysters treated with the antibiotic remained stable between 13 and $20 \mathrm{dpf}$ ( $p=0.476$, Table 1).

\subsection{Enzyme activities and lipid peroxidation}

We observed an interaction in the effects of time and seawater treatment on the activities of $\mathrm{CS}$ and $\mathrm{CCO}$, two key enzymes of aerobic energy metabolism (Fig. 4). In antibiotic treated oysters, CS and CCO activities increased markedly during larval ontogeny. In contrast, $\mathrm{CS}$ and $\mathrm{CCO}$ activities of animals maintained in untreated seawater increased until $13 \mathrm{dpf}$ and decreased markedly (CS) or remained constant (CCO) when mortality occurred at $20 \mathrm{dpf}$. Therefore, both CS and CCO activities were lower in moribund larvae at $20 \mathrm{dpf}$ compared to those of antibiotic treated oysters. Overall, CS activity was positively correlated with $\mathrm{CCO}$ irrespective of seawater treatment (Table 2). Normalization of activities of CS and CCO to protein content revealed different results: CS decreased markedly from 6 to $20 \mathrm{dpf}$ irrespective of seawater treatment whereas $\mathrm{CCO}$ decreased from 6 to $20 \mathrm{dpf}$ in untreated larvae only. In antibiotic treated oysters, CCO increased after 13 dpf (Fig. 4). 
TAG

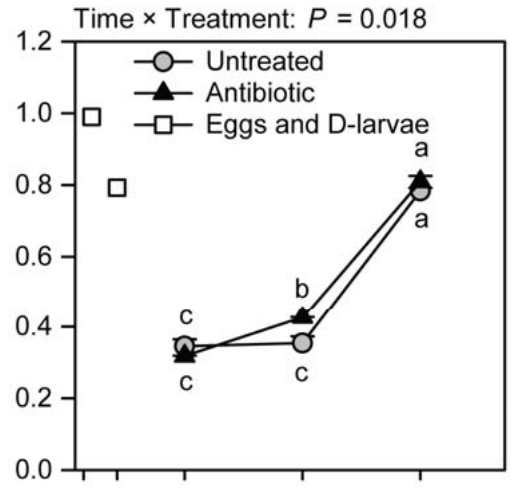

FFA

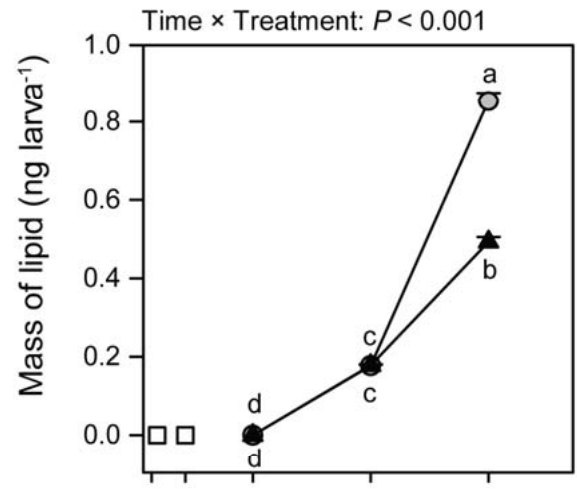

DG

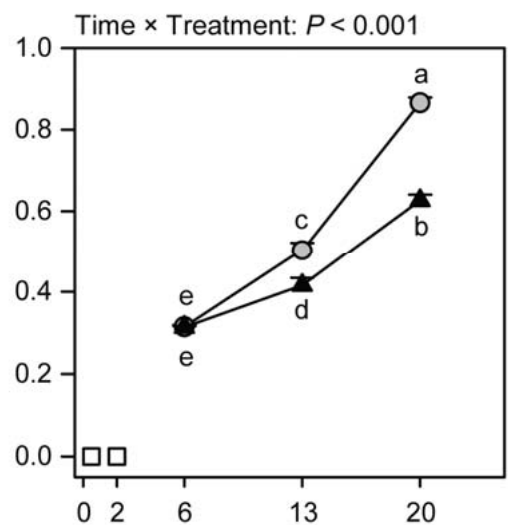

AMPL

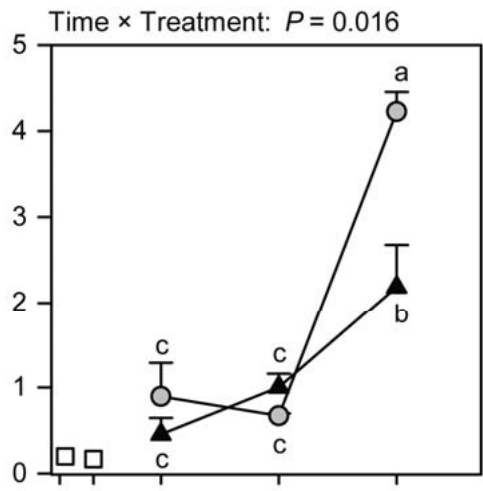

ST

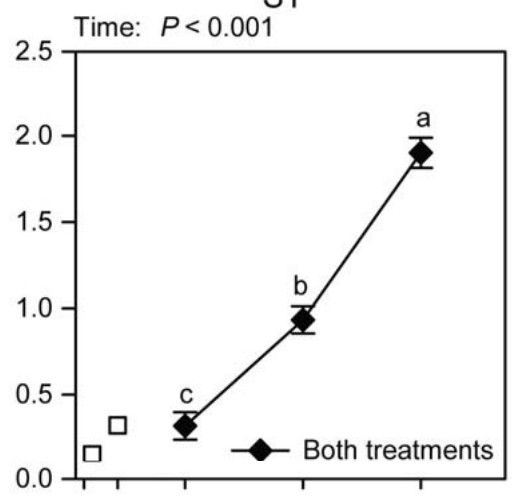

PL

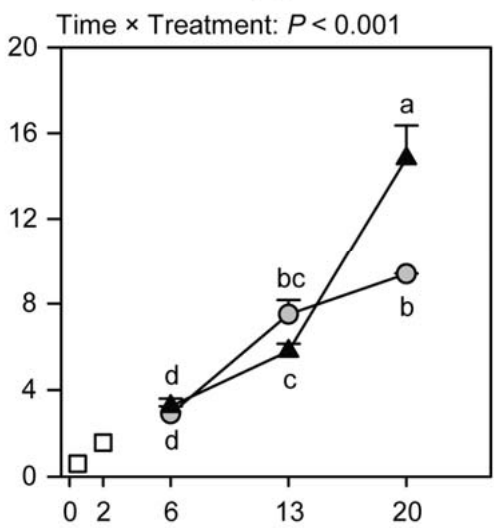

Days post-fertilization (dpf)

Fig. 3. Lipid class composition of American oyster Crassostrea virginica as a function of development time and seawater treatment. Seawater was untreated or treated with an antibiotic. Data from different treatments were pooled when this effect was not significant. Data are means \pm SD of three replicate tanks. Different letters indicate significant differences. TAG: triacylglycerols, FFA: free fatty acids, DG: diacylglycerols, AMPL: acetone mobile polar lipids, ST: sterols, PL: phospholipids.

There were also time and treatment interactions on the effects on CAT, GPX and SOD (Fig. 5). When the massive mortality was observed, CAT and SOD activities were higher in larvae maintained in untreated seawater compared to those of antibiotic treated oysters. At $13 \mathrm{dpf}$, activities of GPX and SOD were higher in untreated larvae compared to that of treated oysters, suggesting an activation of antioxidant defenses before the mortality event in untreated tanks. Overall, antioxidant activities increased during larval ontogeny. Energy metabolism was positively correlated with antioxidant activities in antibiotic treated larvae (Table 2). When results were normalized to protein content, we observed that CAT, GPX and SOD activities increased with time in larvae maintained in untreated water. In antibiotic treatment, only GPX showed an 
Citrate synthase

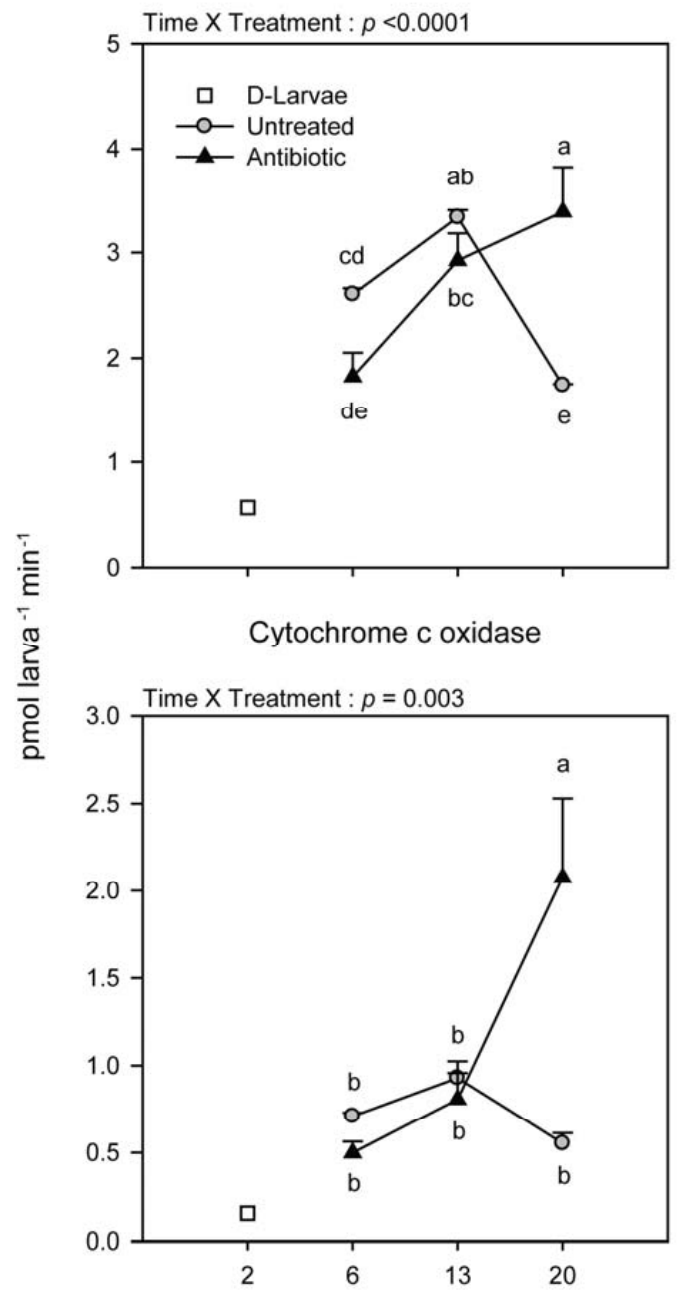

Citrate synthase

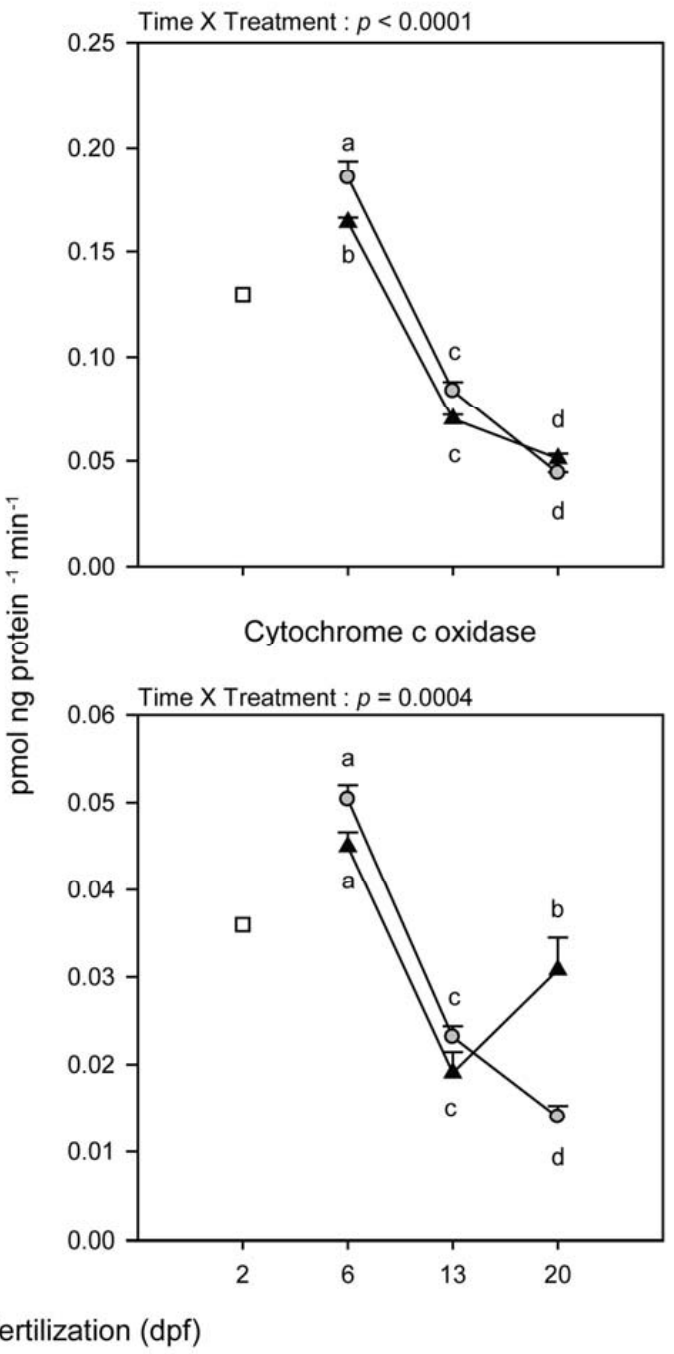

Fig. 4. Metabolism energy activity of American oyster Crassostrea virginica as a function of development time and seawater treatment. Seawater was untreated or treated with an antibiotic. Data are expressed as enzyme activity per larva (left) and specific-protein enzyme activity (right). Data are means $\pm \mathrm{SD}$ of three replicate tanks. Different letters indicate significant differences.

increase between 13 and $20 \mathrm{dpf}$. Moreover, we observed treatment effect on CAT, GPX and SOD at $20 \mathrm{dpf}$ where higher activities were measured in animals reared in untreated water. Similar treatment effect was found for GPX and SOD at 13 dpf.

Finally, lipid peroxidation, as measured by MDA, varied as a function of time $\times$ treatment (Fig. 6). The MDA level increased during larval ontogeny irrespective of seawater treatment. Significant differences between treatments were related to the mortality event at $20 \mathrm{dpf}$, with a peroxidation level $\sim 2$ fold higher in moribund larvae. This value represents the highest value measured in this study $([\mathrm{MDA}]=0.114 \pm 10 \mathrm{pmol}$ $\left.\operatorname{larva}^{-1}\right)$. Energy metabolism and antioxidant activities were positively correlated with lipid peroxidation levels, at least in antibiotic treated larvae (Table 3). These results illustrate that an increase in energy metabolism in the antibiotic treatment coincided with an increase in oxidative stress and antioxidant defenses.

\section{Discussion}

\subsection{Characterization of the massive mortality}

Although some abiotic and biotic factors are known to induce high mortality, it is difficult to precisely determine the origin of the mortality outbreak observed at $20 \mathrm{dpf}$. Antibiotic and untreated larvae showed same growth and survival rates before $20 \mathrm{dpf}$, suggesting that the larval batches had followed the same evolution before the mortality occurrence. Larvae were reared in controlled system (temperature, $\mathrm{pH}$, lighting, oxygenation) and the analyses of seawater did not revealed the presence of specific pollutant in the tanks that could explained the mortality observed. Interestingly, we observed that the surrounding bacterial community evolved on a different way according to the treatment applied. Similarity index declined progressively between antibiotic and untreated larvae to reach the lowest value at $20 \mathrm{dpf}$, which coincided with the 
Table 2. Summary of linear regressions between enzymes involved in energy metabolism and antioxidant activities (activity per larva) in American oyster Crassostrea virginica $(n=9)$.

\begin{tabular}{lllcc}
\hline Regression & Treatment & Equation & $R^{2}$ & $p$ \\
\hline \multirow{2}{*}{ CS vs. CCO } & Antibiotic & CCO $=1.60$ CS -0.58 & 0.79 & $\mathbf{0 . 0 0 1}$ \\
& Untreated & CCO $=0.60$ CS +0.12 & 0.72 & $\mathbf{0 . 0 0 8}$ \\
CS vs. CAT & Antibiotic & CAT $=280$ CS +129 & 0.65 & $\mathbf{0 . 0 0 2}$ \\
& Untreated & n.s. & 0.15 & 0.352 \\
CS vs. GPX & Antibiotic & GPX $=0.63$ CS -0.16 & 0.61 & $\mathbf{0 . 0 0 3}$ \\
& Untreated & n.s. & 0.04 & 0.644 \\
CS vs. SOD & Antibiotic & SOD $=367$ CCO +229 & 0.45 & $\mathbf{0 . 0 1 4}$ \\
& Untreated & n.s. & 0.17 & 0.305 \\
CCO vs. CAT & Antibiotic & CAT $=274$ CCO +148 & 0.60 & $\mathbf{0 . 0 0 3}$ \\
& Untreated & n.s. & 0.03 & 0.668 \\
CCO vs. GPX & Antibiotic & GPX $=0.32$ CCO +0.19 & 0.52 & $\mathbf{0 . 0 0 8}$ \\
& Untreated & n.s. & 0.01 & 0.860 \\
CCO vs. SOD & Antibiotic & SOD $=252$ CCO +247 & 0.74 & $<\mathbf{0 . 0 0 1}$ \\
& Untreated & n.s. & 0.01 & 0.778 \\
CAT vs. GPX & Antibiotic & GPX $=0.002$ CAT -0.29 & 0.71 & $<\mathbf{0 . 0 0 1}$ \\
& Untreated & GPX $=0.001$ CAT +0.09 & 0.91 & $<\mathbf{0 . 0 0 1}$ \\
CAT vs. SOD & Antibiotic & SOD $=1.45$ CAT -84 & 0.91 & $<\mathbf{0 . 0 0 1}$ \\
& Untreated & SOD $=1.33$ CAT -78 & 0.98 & $<\mathbf{0 . 0 0 1}$ \\
GPX vs. SOD & Antibiotic & SOD $=609$ GPX +233 & 0.87 & $<\mathbf{0 . 0 0 1}$ \\
& Untreated & SOD $=1004$ GPX +27 & 0.95 & $<\mathbf{0 . 0 0 1}$ \\
\hline
\end{tabular}

Significant probabilities are in bold. CS: citrate synthase, CCO: cytochrome oxidase, CAT: catalase, GPX: glutathione peroxidase, SOD: superoxide dismutase, n.s. not significant.

Table 3. Summary of linear regressions between enzyme activities (activity per larva) and malondialdehyde (MDA, content per larva) concentration in American oyster Crassostrea virginica $(n=9)$.

\begin{tabular}{lllcc}
\hline Regression & Treatment & Equation & $R^{2}$ & $p$ \\
\hline \multirow{2}{*}{ CS vs. MDA } & Antibiotic & MDA $=0.03 \mathrm{CS}-0.01$ & 0.75 & $<\mathbf{0 . 0 0 1}$ \\
& Untreated & n.s. & 0.42 & 0.081 \\
& Antibiotic & MDA $=0.02 \mathrm{CCO}+0.01$ & 0.82 & $<\mathbf{0 . 0 0 1}$ \\
CCO vs. MDA & Untreated & n.s. & 0.21 & 0.259 \\
& Antibiotic & MDA $=0.0001$ CAT -0.01 & 0.92 & $<\mathbf{0 . 0 0 1}$ \\
CAT vs. MDA & Untreated & MDA $=0.0001$ CAT -0.02 & 0.90 & $<\mathbf{0 . 0 0 1}$ \\
& Antibiotic & MDA $=0.04$ GPX +0.01 & 0.79 & $<\mathbf{0 . 0 0 1}$ \\
GPX vs. MDA & Untreated & MDA $=0.09$ GPX -0.02 & 0.74 & $\mathbf{0 . 0 0 6}$ \\
& Antibiotic & MDA $=0.0001$ SOD -0.01 & 0.97 & $<\mathbf{0 . 0 0 1}$ \\
SOD vs. MDA & Untreated & MDA $=0.0001$ SOD -0.02 & 0.84 & $\mathbf{0 . 0 0 1}$ \\
\hline
\end{tabular}

Significant probabilities are in bold. CS: citrate synthase, CCO: cytochrome oxidase, CAT: catalase, GPX: glutathione peroxidase, SOD: superoxide dismutase, n.s. not significant.

lowest number of cultivable bacterial and presumptive vibrio loads. These results illustrated the progressive action of the antibiotic on the bacterial community. The improvement of larval survival following chloramphenicol treatment has been previously measured in bivalve hatcheries (Nicolas et al. 1996; Gomez-Leon et al. 2005; Torkildsen et al. 2005). It was suggested in these previous researches that protective effect was probably due to capacity of chloramphenicol to decrease the bacterial load in larval tanks, limiting the proliferation of opportunistic pathogens and thus avoiding the occurrence of massive mortality; However, the use of antibiotic favour the selection of resistant bacteria which represent some risks for health and environment. Other methods such as probiotics were proposed as alternative to antibiotic (Kersarcodi-Watson et al. 2008, Prado et al. 2010). The presence of a bacterial pathogen could not be certainly demonstrated, but the higher counts on
TCBS plate at 13 and $20 \mathrm{dpf}$ in untreated tanks and the observations of bacillary necrosis symptoms related to Vibrio infection in C. virginica larvae (Tubiash et al. 1965; Elston and Leibovitz 1980; Estes et al. 2004), suggest the possibility of pathogen infection in the untreated tanks.

Our results suggest that untreated larvae progressively reduced their feeding activity before the massive mortality event while antibiotic treated larvae significantly increased their feeding activity after $15 \mathrm{dpf}$. The microscopic observations of moribund larvae at $20 \mathrm{dpf}$ showing larvae weakly swimming in circles with their velum partially retracted or reduced suggested that the progressive decrease and cessation of feeding in untreated larvae could be linked to a degeneration of the velum, which is the principal larval feeding organ. The impact of disease on the feeding activity of adult $C$. virginica is well documented (Ward and Langdon 1986; Gale et al. 1991). 

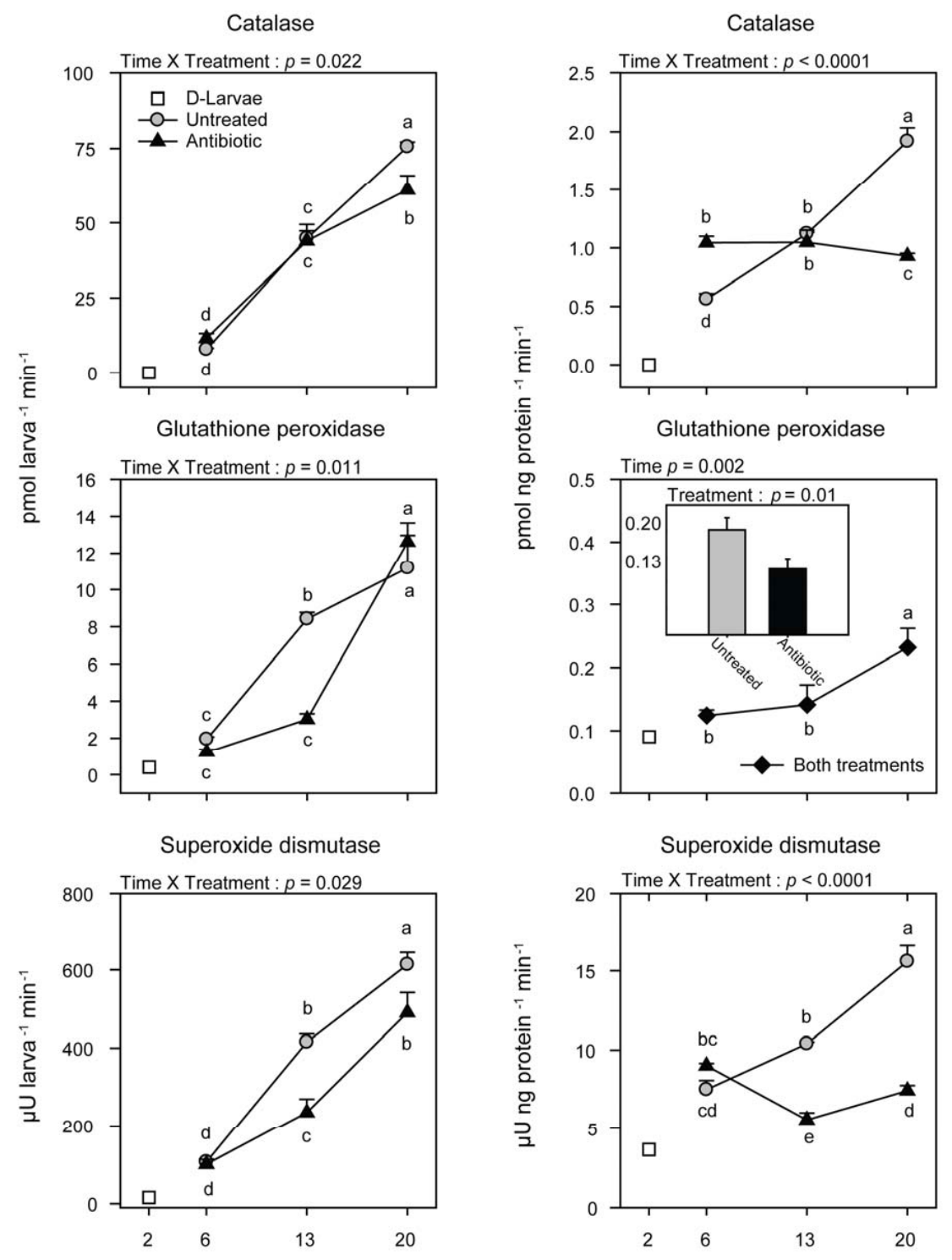

Days post-fertilization (dpf)

Fig. 5. Antioxidant enzyme activities of American oyster Crassostrea virginica as a function of development time and seawater treatment. Seawater was untreated or treated with an antibiotic. Main effects were plotted when interaction was not significant. Data are expressed as enzyme activity per larva (left) and specific-protein enzyme activity (right). Data are means \pm SD of three replicate tanks. Different letters indicate significant differences.

The higher concentration of FFA, DG and AMPL in moribund larvae may reflect TAG and PL catabolism. Indeed, FFA, DG and monoacylglycerides (included in the AMPL) usually result from TAG and PL degradation by lipase (Derewenda 1994; Sewell 2005).

The mass mortality was associated with few change on the fatty acid composition of polar lipids. Only the level of naturally biosynthesized 22:2 NMI fatty acid was higher in untreated larvae at $20 \mathrm{dpf}$, when the mass mortality occurred, compared to untreated oysters at $13 \mathrm{dpf}$ and oysters treated with the antibiotic. An increase in 22:2 NMI may compensate for the decrease in other long-chain PUFA (such as DHA) and the decrease in the peroxidation index of polar lipids attributable to the oxidative stress related to the mass mortality. This hypothesis is supported by the fact that NMI fatty acids are more resistant to oxidation than other PUFA (Klingensmith 1982). It was also suggested that since NMI fatty acids usually occur in the outer membrane of mollusks, their presence may increase the resistance to attack by microbial lipases (Ackman and Hooper 1973).

Mass mortality was also characterized by arrested accumulation of protein and PL in moribund larvae, suggesting a possible catabolism of these constituents. Utilisation of protein as energetic reserves in oyster larvae was well documented (Garcia-Esquivel et al. 2002; Moran and Manahan 2004). Moreover, the progressive cessation of feeding activity 


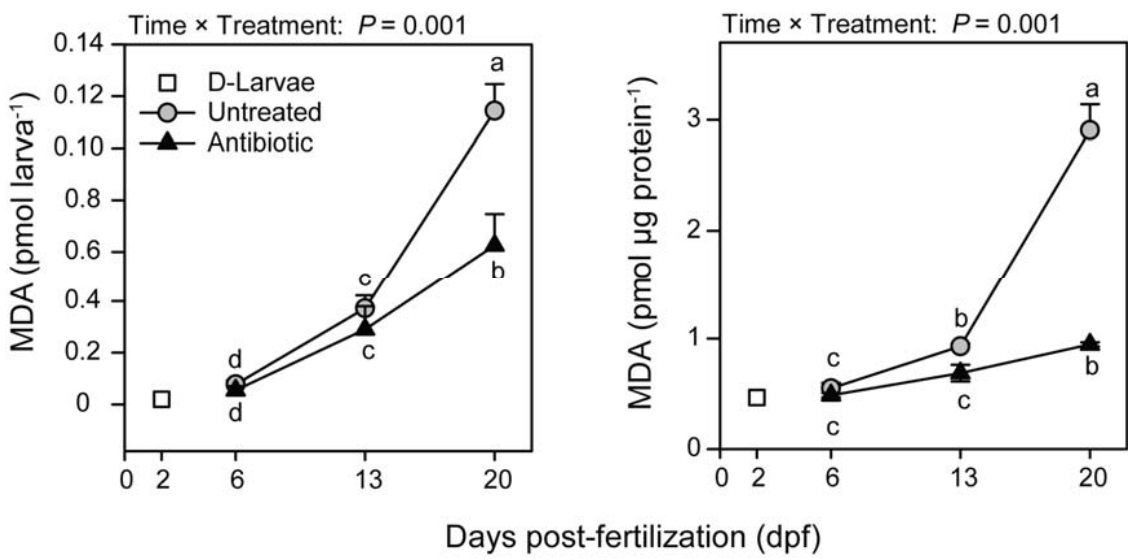

Fig. 6. Lipid peroxidation levels as measured by malondialdehyde (MDA) in American oyster Crassostrea virginica as a function of development time and seawater treatment. Seawater was untreated or treated with an antibiotic. Data are expressed as MDA concentration per larva (left) and per protein content (right). Data are means \pm SD of three replicate tanks. Different letters indicate significant differences.

in untreated larvae before mortality appearance could induce a decrease of protein synthesis. Indeed, the impact of starvation on protein content has been demonstrated in several marine invertebrate species (Moran and Manahan 2003, 2004; Meyer et al. 2007). Regarding the PL, we suggest two possible explanations. First, a portion of the fatty acids from PL could be oxidized ( $\beta$-oxidation) to respond to the increased energy demand, as observed by Gallager et al. (1986) in starved C. virginica larvae. Second, the lower PL content could be a result of extracellular phopsholipase activity by the putative pathogens. Phospholipase activity has been linked to pathogenesis in bacterial species (Testa et al. 1984; Schmiel and Miller 1999; see the review of Istivan and Coloe 2006). The higher FFA content in infected larvae could be linked to this phospholipase activity. However, the validation of this hypothesis would require further specific analyses on membrane integrity and phospholipase activity.

Moribund $C$. virginica larvae showed significant decreases in $\mathrm{CS}$ and $\mathrm{CCO}$ activities, suggesting a decline in energy production. This metabolic depression could be explained by a lack of energy substrate due to limited feeding, as reported in starved C. gigas (Moran and Manahan 2004; Ben Kheder et al. 2010b). The decreases in CS and CCO activities could indicate a decline in respiration rate. Indeed, several studies on marine invertebrates have shown that respiration rate and CS activity were positively correlated (Moran and Manahan 2004; Meyer et al. 2007). In juvenile Manila clams, respiration rate decreased with the development of brown ring disease symptoms (Flye-Sainte-Marie et al. 2007). These authors observed that the oxygen consumption decrease was correlated with decreased feeding (clearance rate) and could be interpreted as a compensatory reduction of metabolic rate, as was observed by Widdows and Hawkins (1989).

Moribund larvae showed an increase in antioxidant enzymes between 13 and $20 \mathrm{dpf}$ that is not attributable to an increase in respiratory activity. This implies another origin of ROS production, for example, a possible increase of ROS associated with the immune response. In bivalves, ROS production during infection have been suggested to be a host defense mechanism to counter attacks of pathogenic bacteria
(Canesi et al. 2002; Lambert et al. 2003; Labreuche et al. 2006b; Wang et al. 2010). The increase of CAT, GPX and SOD protein-specific activity shows that moribund larvae increased the proportion of antioxidant enzymes in their tissues, thus pinpointing the importance of antioxidant defenses during the massive mortality event.

The massive mortality event coincided with a higher level of lipid peroxidation, as measured by the peroxidation index of polar lipids and MDA, suggesting higher oxidative stress in moribund larvae. This difference in lipid peroxidation levels was accompanied by a slightly higher antioxidant activity. We hypothesized that until $13 \mathrm{dpf}$, untreated larvae possessed antioxidant defenses capable of limiting oxidative stress and lipid peroxidation. After this period, the lack of energy production (as suggested by CS and CCO activities) coupled with a potential increase in the generation of ROS for the immune response did not allow the larvae to develop adequate antioxidant defenses to efficiently resist the pathogen challenge. Thus the increase in lipid peroxidation could reflect a saturation in enzymatic antioxidant defenses in moribund larvae.

\subsection{Development and performance of oyster larvae}

In our study, growth rates and TAG levels in $C$. virginica larvae were markedly lower than those reported by others in the same species (Chu and Webb 1984; Gallager et al. 1986). Indeed, growth rates and TAG levels in healthy $C$. virginica are respectively 3-51 $\mu \mathrm{m} \mathrm{d}^{-1}$ and 3.6-11.1 $\mathrm{ng} \mathrm{larva}^{-1}$ (Chu and Webb 1984) compared to our results of $1.3-8.4 \mu \mathrm{m} \mathrm{day}^{-1}$ and $0.9 \mathrm{ng}$ larva $^{-1}$ at $20 \mathrm{dpf}$ in this work. Fast growth is achieved by a combination of increased feeding rates, reduced metabolic rates and lower metabolic costs of growth. These physiological traits show intraspecific variation, and some of them are heritable in bivalves (Bayne 2004). Given that the oysters used in this study were fed ad libidum, it is likely that their low performance is related to a batch effect.

Our results show that ontogeny rather than the seawater treatment was the main factor affecting levels of the major long-chain PUFA such as 22:6n-3 (DHA), 20:5n-3 (EPA) and 
20:4n-6 (ARA). DHA in C. virginica was maintained at higher levels than that in the diet and increased during larval ontogeny until reaching a plateau. In addition, DHA was preferentially accumulated and/or retained at the expense of EPA. These observations agree with the important role that DHA plays during larval development, as has already been reported in the polar lipids of other bivalve larvae (Delaunay et al. 1993; Farias et al. 2003; Pernet et al. 2005).

In contrast, ARA increased during the embryonic development of $C$. virginica and declined markedly during larval ontogeny to below dietary levels. This result contrasts with those reported in other bivalve species, where an increase in ARA was observed in early development (Pernet et al. 2005; Rico-Villa et al. 2006). A similar decrease in ARA from polar lipids was previously observed in Pecten maximus larvae fed low-ARA phytoplankton species (Delaunay et al. 1993). However, the dietary level of ARA was ca. $3.3 \%$ in our study and cannot be considered as deficient. Therefore, utilization of ARA from polar lipids during the larval ontogeny of American oysters needs further investigation.

The CS and CCO activities increased in the antibiotic treatment between 13 and $20 \mathrm{dpf}$, corresponding to a period of increasing feeding activity and energetic reserves accumulation (protein and TAG). This observation suggests an increase of energy metabolism with ontogeny when food is available, as has been demonstrated in several marine invertebrate species (Moran and Manahan 2003, 2004; Meyer et al. 2007). Proteinspecific activities of CS and CCO increased during larval ontogeny and reflect overall increase in total protein content, as previously reported in C. gigas by Moran and Manahan (2004).

Parallel to this, we measured an increase in the activities of antioxidant enzymes and lipid peroxidation during larval development in American oysters. As observed for energetic metabolism enzymes, protein-specific activities of antioxidant enzymes increased during larval ontogeny and reflect overall increase in total protein content, except for GPX. The correlation between energetic metabolism and antioxidant enzymes as well as that between energetic metabolism and lipid peroxidation in the antibiotic treatment seem to indicate that antioxidant defenses adapt to the increased ROS generation during energy production (Nohl et al. 2003, 2005). Such correlations have been demonstrated in other organisms, such as polychetes (Marie et al. 2006), fish (Morales et al. 2004) and mammals (Leeuwenburgh et al. 1997). However, the role of ROS and antioxidants during embryonic and larval development of aquatic animals in general and invertebrates in particular has been little studied (Dandapat et al. 2003; Regoli et al. 2005; Kalaimani et al. 2007). During egg and embryonic development, a gradual increase in oxygen uptake was seen in the prawn Macrobrachium malcolmsonii that appeared to be counteracted by an increase in CAT, GPX and SOD activities (Dandapat et al. 2003), illustrating the importance of antioxidant defenses in marine invertebrate larval development.

\section{Conclusion}

In summary, this study improves our understanding of the mass mortality phenomena that affect bivalve hatcheries. We showed that mortality in oyster larvae coincided with strong changes in the surrounding bacterial community that could affect larval development at different levels. Mortality emergence causes a progressive decrease in the feeding activity of untreated larvae, affecting their ability to recover their energy reserves and resulting in a decrease of energy production, as suggested by lower CCO and CS activities. This low energy availability could reduce the efficiency of the antioxidant defenses, leading to an increase in lipid peroxidation and finally to the mass mortality event. This study also allowed us to characterize ontogenic changes in lipid classes and fatty acid composition as well as in metabolic and antioxidant enzymes.

Acknowledgements. The authors are grateful to the IRZC staff for oyster production. Thanks are addressed to Laure Devine for linguistic revision. This study was supported by grants from the Natural Sciences and Engineering Research Council of Canada and the Réseau Aquacole du Québec to F.P. and R.T.

\section{References}

Ackman R.G., Hooper S.N., 1973, Non-methylene-interrupted fatty acids in lipids of shallow-water marine invertebrates, a comparison of two molluscs (Littorina littorea and Lunatia triseriata) with the sand shrimp (Crangon septemspinosus). Comp. Biochem. Physiol. B. Biochem. Mol. Biol. 46, 153-165.

Bayne B.L., 2004, Phenotypic flexibility and physiological tradeoffs in the feeding and growth of marine bivalve molluscs. Integr. Comp. Biol. 44, 425-432.

Bell J.G., Sargent J.R., 2003, Arachidonic acid in aquaculture feeds, current status and future opportunities. Aquaculture 218, 491499.

Ben Kheder, R., Queré, C., Moal, J., Robert, R., 2010a, Effect of nutrition on Crassostrea gigas development and the evolution of physiological indices, Part A: Quantitative and qualitative diet effects. Aquaculture 305, 165-173.

Ben Kheder, R., Quere, C., Moal, J., Robert, R., 2010b, Effect of nutrition on Crassostrea gigas larval development and the evolution of physiological indices, Part B: Effects of temporary food deprivation. Aquaculture 308, 174-182.

Canesi L., Gallo G., Gavioli M., Pruzzo C., 2002, Bacteria-hemocyte interactions and phagocytosis in marine bivalves. Microsc. Res. Techniq. 57, 469-476.

Childress J.J., Somero G.N., 1979, Depth-related enzyme activities in muscle, brain and heart of deep-living pelagic marine teleosts. Mar. Biol. 52, 272-283.

Chu F.-L., Webb K.L., 1984, Polyunsaturated fatty acids and neutral lipids in developing larvae of the oyster Crassostrea virginica. Lipids 19, 815-820.

Dandapat J., Chainy G.B.N., Rao K.J., 2003, Lipid peroxidation and antioxidant defense status during larval development and metamorphosis of giant prawn, Macrobrachium rosenbergii. Comp. Biochem. Physiol. C. Pharmacol. Toxicol. Endocrinol. 135, 221233.

Delaunay F., Marty Y., Moal J., Samain J.-F., 1992, Growth and lipid class composition of Pecten maximus (L.) larvae grown under hatchery conditions. J. Exp. Mar. Biol. Ecol. 163, 209-219.

Delaunay F., Marty Y., Moal J., Samain J.-F., 1993, The effect of monospecific algal diets on growth and fatty acid composition of Pecten maximus (L.) larvae. J. Exp. Mar. Biol. Ecol. 173, 163179. 
Derewenda Z.S., 1994, Structure and function of lipases. Adv. Protein Chem. 45, 1-52.

Elston R., Leibovitz L., 1980, Pathogenesis of experimental vibriosis in larval American oysters, Crassostrea virginica. Can. J. Fish. Aquat. Sci. 37, 964-978.

Estes R.M., Friedman C.S., Elston R.A., Herwig R.P., 2004, Pathogenicity testing of shellfish hatchery bacterial isolates on Pacific oyster Crassostrea gigas larvae. Dis. Aquat. Org. 58, 223 230.

Farias A., Bell, J.G., Uriarte I., Sargent J.R., 2003, Polyunsaturated fatty acids in total lipid and phospholipids of Chilean scallop Argopecten purpuratus (L.) larvae, effects of diet and temperature. Aquaculture 228, 289-305.

Flohé L., Ötting F., 1985, Superoxide dismutase assays. Methods Enzymol. 150, 93-104.

Flye-Sainte-Marie J., Pouvreau S., Paillard C., Jean F., 2007, Impact of Brown Ring Disease on the energy budget of the Manila clam Ruditapes philippinarum. J. Exp. Mar. Biol. Ecol. 349, 378-389.

Folch J., Lees M., Sloane-Stanley G.H., 1957, A simple method for the isolation and purification of total lipids from animal tissues. J. Biol. Chem. 226, 497-509.

Gale L.D., Manzi J.J., Crosby M.P., 1991, Energetic costs to the eastern oyster Crassostrea-virginica due to recent parasitism by the ectoparasitic gastropod Boonea impressa. Mar. Ecol. Prog. Ser. 79, 89-98.

Gallager S.M., Mann R., Sasaki G.C., 1986, Lipid as an index of growth and viability in three species of bivalve larvae. Aquaculture 56, 81-103.

Garcia-Esquivel Z., Bricelj V.M., Felbeck H., 2002, Metabolic depression and whole-body response to enforced starvation by Crassostrea gigas postlarvae. Comp. Biochem. Physiol. 133, 6377.

Gomez-Leon J., Villamil L., Lemos M.L., Novoa B., Figueras A., 2005, Isolation of Vibrio alginolyticus and Vibrio splendidus from aquacultured carpet shell clam (Ruditapes decussatus) larvae associated with mass mortalities. Appl. Environ. Microbiol. 71, 98104.

Griffiths S., Melville K., Cook M., Vincent S., St Pierre M., Lanteigne C., 2001, Profiling of bacterial species associated with haddock larviculture by PCR amplification of $16 \mathrm{~S}$ rDNA and denaturing gradient gel electrophoresis. J. Aquat. Anim. Health. 13, 355363.

Guillard R.R.L. 1975, Culture of phytoplankton for feeding marine invertebrates. In: Smith W.L., Chanley M.H. (Eds.), Culture of Marine Invertebrate Animals, New York, Plenum Press, pp. 29 60.

Holland D.L., Spencer B.E., 1973, Biochemical changes in fed and starved oysters, Ostrea edulis L. during larval development, metamorphosis and early spat growth. J. Mar. Biol. Assoc. UK 53, 287-298.

Istivan T.S., Coloe P.J., 2006, Phospholipase A in Gram-negative bacteria and its role in pathogenesis. Microbiology 152, 1263-1274.

Ivanina, A.V., Froelich, B., Williams, T., Sokolov, E.P., Oliver, J.D., Sokolova, I.M., 2011, Interactive effects of cadmium and hypoxia on metabolic responses and bacterial loads of eastern oysters Crassostrea virginica Gmelin. Chemosphere 82, 377-389.

Kesarcodi-Watson A., Kaspar H., Lategan M.J., Gibson L., 2008, Probiotics in aquaculture: the need, principles and mechanisms of action and screening processes. Aquaculture 274, 1-14.

Klingensmith J.S., 1982, Distribution of methylene and nonmethylene-interrupted dienoic fatty acids in polar lipids and triacylglycerols of selected tissues of the hardshell clam (Mercenaria mercenaria). Lipids 17, 976-981.
Labreuche Y., Soudant P., Goncalves M., Lambert C., Nicolas J.L., 2006a, Effects of extracellular products from the pathogenic Vibrio aestuarianus strain 01/32 on lethality and cellular immune responses of the oyster Crassostrea gigas. Dev. Comp. Immunol. 30, 367-379.

Labreuche Y., Lambert C., Soudant P., Boulo V., Huvet A., Nicolas J.L., 2006b, Cellular and molecular hemocyte responses of the Pacific oyster, Crassostrea gigas, following bacterial infection with Vibrio aestuarianus strain 01/32. Microbes Infect. 8, 27152724.

Lambert C., Soudant P., Choquet G., Paillard C., 2003, Measurement of Crassostrea gigas hemocyte oxidative metabolism by flow cytometry and the inhibiting capacity of pathogenic vibrios. Fish Shellfish Immunol. 15, 225-240.

Lambert C., Soudant P., Degremont L., Delaporte M., Moal J., Boudry P., Jean F., Huvet A., Samain J.F., 2007, Hemocyte characteristics in families of oysters, Crassostrea gigas, selected for differential survival during summer and reared in three sites. Aquaculture 270, 276-288.

Langdon C.J., Waldock M.J., 1981, The effect of algal and artificial diets on the growth and fatty acid composition of Crassostrea gigas spat. J. Mar. Biol. Assoc. UK 61, 431-448.

Lepage G., Roy C.C., 1984, Improved recovery of fatty acid through direct transesterification without prior extraction or purification. J. Lipid Res. 25, 1391-1396.

Leeuwenburgh C., Hollander J., Leichtweis S., GriYths N., Gore M., Ji L.L., 1997, Adaptations of glutathione antioxidant system to endurance training are tissue and muscle fiber specific. Am. J. Physiol. 272, R363-R369.

Marie B., Génard B., Rees J.F., Zal F., 2006, Effect of ambient oxygen concentration on activities of enzymatic antioxidant defences and aerobic metabolism in the hydrothermal vent worm, Paralvinella grasslei. Mar. Biol. 150, 273-284.

McCord J.M., Fridovich I., 1969, Superoxide Dismutase, an enzymic function for erythrocuprein (hemocuprein). J. Biol. Chem. 244, 6049-6055.

Meyer E., Green A.J., Moore M., Manahan D.T., 2007, Food availability and physiological state of sea urchin larvae (Strongylocentrotus purpuratus). Mar. Biol. 152, 179-191.

Morales A.E., Perez-Jimenez A., Hidalgo M.C., Abellan E., Cardenete G., 2004, Oxidative stress and antioxidant defenses after prolonged starvation in Dentex dentex liver. Comp. Biochem. Physiol. 139, 153-161.

Moran A.L., Manahan D.T., 2003, Energy metabolism during larval development of green and white abalone, Haliotis fulgens and $H$. sorenseni. Biol. Bull. 204, 270-277.

Moran A.L., Manahan D.T., 2004, Physiological recovery from prolonged "starvation" in larvae of the Pacific oyster Crassostrea gigas. J. Exp. Mar. Biol. Ecol. 306, 17-36.

Nicolas J.L., Corre S., Gauthier G., Robert R., Ansquer D., 1996, Bacterial problems associated with scallop Pecten maximus larval culture. Dis. Aquat. Org. 27, 67-76.

Nohl H., Gille L., Staniek K., 2005, Intracellular generation of reactive oxygen species by mitochondria. Biochem. Pharmacol. 69, 719-723.

Nohl H., Kozlov A.V., Gille L., Staniek K., 2003, Cell respiration and formation of reactive oxygen species, facts and artefacts. Biochem. Soc. Trans. 31, 1308-1311.

Paglia D.E., Valentine W.N., 1967, Studies on the quantitative and qualitative characterization of erythrocyte glutathion peroxidase. J. Lab. Clin. Med. 70, 158-168.

Paillard C., Le Roux F., Borrego J.J., 2004, Bacterial disease in marine bivalves, a review of recent studies: Trends and evolution. Aquat. Living Resour. 17, 477-498. 
Parrish C.C., 1999, Determination of total lipid, lipid classes, and fatty acids in aquatic samples. In, Arts M.T., Wainman B.C. (Eds.), Lipids in Freshwater Ecosystems, New York, SpringerVerlag, pp. 5-20

Pernet F., Bricelj V.M., Cartier S., 2006a, Lipid class dynamics during larval ontogeny of sea scallops, Placopecten magellanicus, in relation to metamorphic success and response to antibiotics. J. Exp. Mar. Biol. Ecol. 329, 265-280.

Pernet F., Bricelj V.M., Parrish C.C., 2005, Effect of varying dietary levels of omega 6 polyunsaturated fatty acids during the early ontogeny of the sea scallop, Placopecten magellanicus. J. Exp. Mar. Biol. Ecol. 327, 115-133.

Pernet F., Pelletier C.J., Milley J., 2006b, Comparison of three solidphase extraction methods for fatty acid analysis of lipid fractions in tissues of marine bivalves. J. Chromatogr. A 1137, 127-137.

Plante S., Pernet F., Hache R., Ritchie R., Ji B., McIntosh D., 2007, Ontogenetic variations in lipid class and fatty acid composition of haddock larvae Melanogrammus aeglefinus in relation to changes in diet and microbial environment. Aquaculture 263, 107-121.

Prado S., Romalde J.L., Barja J.L., 2010, Review of probiotics for use in bivalve hatcheries. Vet. Microbiol. 145, 187-197.

Regoli F., Nigro M., Benedetti M., Fattorini D., Gorbi S., 2005, Antioxidant efficiency in early life stages of the Antarctic silverfish, Pleuragramma antarcticum, responsiveness to pro-oxidant conditions of platelet ice and chemical exposure. Aquat. Toxicol. $75,43-52$.

Rico-Villa B., Le Coz J.R., Mingant C., Robert R., 2006, Influence of phytoplankton diet mixtures on microalgae consumption, larval developement and settlement of the Pacific oyster Crassostrea gigas (Thunberb). Aquaculture 256, 377-388.

Samain J.F., Degremont L., Soletchnik P., Haure J., Bedier E., Ropert M., Moal J., Huvet A., Bacca H., Van Wormhoudt A., Delaporte M., Costil K., Pouvreau S., Lambert C., Boulo V., Soudant P., Nicolas J.L., Le Roux F., Renault T., Gagnaire B., Geret F., Boutet I., Burgeot T., Boudry P., 2007, Genetically based resistance to summer mortality in the Pacific oyster (Crassostrea gigas) and its relationship with physiological, immunological characteristics and infection processes. Aquaculture 268, 227-243.
Schmiel D.H., Miller V.L., 1999, Bacterial phospholipases and pathogenesis. Microb. Infect. 1, 1103-1112.

Sewell M.A., 2005, Utilization of lipids during early development of the sea urchin Evechinus chloroticus. Mar. Ecol. Prog. Ser. 304 133-142.

Smith W.L., Murphy R.C., 2003, The eicosanoids, cyclooxygenase, lipoxygenase, and epoxygenase pathways. In: Vance D.E., Vance J.E. (Eds.), Biochemistry of lipids, lipoproteins and membranes, Vol. 36, Amsterdam, Elsevier Science, pp. 341-371.

Testa J., Daniel L.W., Kreger A.S., 1984, Extracellular Phospholipase A2 and Lysophospholipase Produced by Vibrio vulnificus. Infect. Immunol. 45, 458-463.

Torkildsen L., Lambert C., Nylund A., Magnesen T., Bergh, O., 2005, Bacteria associated with early life stages of the great scallop, Pecten maximus, impact on larval survival. Aquac. Int. 13, 575592.

Tubiash H.S., Chanley P.E., Leifson E., 1965, Bacillary necrosis, a disease of larval and juvenile bivalve mollusks. J. Bacteriol. 90, 1036-1044.

Wang S.L., Peatman E., Liu H., Bushek D., Ford S.E., Kucuktas H., Quilang J., Li P., Wallace R., Wang Y.P., Guo X.M., Liu Z.J., 2010, Microarray analysis of gene expression in eastern oyster (Crassostrea virginica) reveals a novel combination of antimicrobial and oxidative stress host responses after dermo (Perkinsus marinus) challenge. Fish Shellfish Immunol. 29, 921-929.

Ward J.E., Langdon C.J., 1986, Effects of the ectoparasite Boonea (Odostomia) impressa (Say) Gastropoda pyramidellidae, on the growth rate, filtration rate and valve movements of the host Crassostrea virginica (Gmelin). J. Exp. Mar. Biol. Ecol. 99, 163180.

Widdows J., Hawkins A.J.S., 1989, Partitioning of rate of heat dissipation by Mytilus edulis into maintenance, feeding, and growth components. Physiol. Zool. 62, 764-784.

Yonetani T., 1967, Cytochrome oxidase, beef heart. Methods Enzymol. 10, 332-335. 